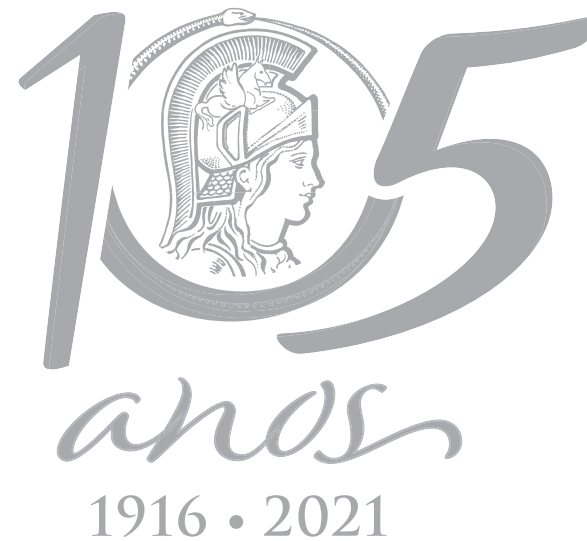

$1916 \cdot 2021$

\title{
Structure and diversity of bacterial community in semiarid soils cultivated with prickly- pear cactus (Opuntia ficus-indica (L.) Mill.)
}

\author{
MARIA DO CARMO C.P. DE LYRA, RODRIGO G. TAKETANI, ANA DOLORES DE \\ FREITAS, CAROLINA E.R.S. E SILVA, ADÁLIA C.E.S. MERGULHÃO, \\ MARIA LUIZA R.B. DA SILVA, JADSON E.L.S. ANTUNES, ADEMIR S.F. DE ARAÚJO \& \\ POLIANA F. GIACHETTO
}

\begin{abstract}
Studies evaluating the structure and diversity of bacterial communities in arid environments including the rhizosphere of local and adapted plant species are important. Therefore, we used a sequencing of the $16 \mathrm{~S}$ ribosomal RNA gene for describing the structure and diversity of soil bacterial community in three zones: Agreste, Transition and Sertão. The bacterial community was clustered in 9,838 OTUs in Agreste, 8,388 OTUs in the transition, and 14,849 OTUs for Sertão. Among the most abundant phyla, Proteobacteria and Acidobacteria were abundant in Agreste and Sertão, respectively, while Actinobacteria were abundant in Transition and Sertão. Specific taxa of Proteobacteria, in Agreste, and Actinobacteria, in Sertão, exhibited differences according to biotic and abiotic conditions. Thus, the structure and diversity of bacterial community were different in these areas and were influenced by environmental and soil conditions.
\end{abstract}

Key words: Caatinga biome, metagenomics, microbial communities, diversity.

\section{INTRODUCTION}

Caatinga is an important biome in Brazil that presents high temperature, intense contrasts between seasons and differences in soil conditions. Also, the rainfall distribution is concentrated in three to four months per year (De BM Trovão et al. 2007). These characteristics associated with the improper use of the Caatinga soils can contribute for desertification (Kavamura et al. 2013, Silva et al. 2004).

specifically, the caatinga region from Pernambuco state presents two distinct mesoregions known as Agreste and Sertão. Agreste presents annual average temperatures of $25^{\circ} \mathrm{C}$ and rainfall of $1,200 \mathrm{~mm}$, while Sertão presents lowest rainfall (400 $\mathrm{mm}$ per year) and highest temperature (annual average of $42^{\circ} \mathrm{C}$ ). In these regions, the Prickly-Pear Cactus is a plant species adapted to these adverse weather conditions. Due to its photosynthetic process known as crassulacean acid metabolism (CAM) (Magalhães \& Ferri 1979). Also, this plant is important as the main source of animal feed during the dry period.

On the other hand, different environmental conditions found in Agreste and Sertão found in both regions could influence the microbial community found in soils. The knowledge of how microbial communities interact with this plant is important for understanding of its responses to environmental shifts. Specially, bacterial community plays important roles in the 
soil ecosystem and is responsible for processes such as organic matter decomposition, being influenced by biotic and abiotic factors, such as soil temperature and moisture. The relationship between bacterial species may be influenced by the plant species present in the soil (Klindworth et al. 2013).

Plants are essential for soil microbial function and structure (Bardgett 2005, Bais et al. 2006, Horner-Devine et al. 2004) and the rhizosphere characteristics influence the composition of bacterial community in soil (Philippot et al. 2013). Natural ecosystems such as the Caatinga, plant species and their capacity are influenced by the availability of nutrients in the soil. Mechanisms that differentially affect the responses of plants as well as the microbiome of rhizosphere (Philippot et al. 2013). Thus, the structure and diversity of microbial community is important for indicating changes in soil quality in many ecosystems, such as Caatinga. On the other hand, the bacterial community associated with Prickly-Pear Cactus in Caatinga biome has not been studied yet. We hypothesized that there may be differences in the structure and diversity of bacterial community in rhizosphere of Prickly-Pear Cactus found in Agreste and Sertão, including the transition between regions, since these regions present different environmental conditions. Thus, this study assessed the structure and diversity of bacterial community in the rhizosphere of Prickly-Pear Cactus in three different regions: Agreste, Transition, and Sertão.

\section{MATERIALS AND METHODS}

Soils were sampled in three different areas with Prickly-Pear Cactus belonging to the Agronomic Institute of Pernambuco and are distributed throughout the state of Pernambuco: Agreste ( $8^{\circ} 14^{\prime} 18^{\prime \prime} \mathrm{S}$ and $\left.35^{\circ} 55^{\prime} 20^{\prime \prime} \mathrm{W}\right)$; Transition
Agreste-Sertão ( $8^{\circ} 25^{\prime} 08^{\prime \prime} \mathrm{S}$ and $\left.37^{\circ} 03^{\prime} 00^{\prime \prime} \mathrm{W}\right)$;

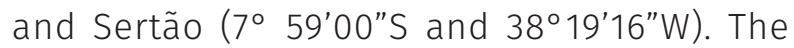
Transition Area is located in the beginning of Sertão (an area well characterized as arid) and the end of Agreste (a less arid region.). Each area $\left(400 \mathrm{~m}^{2}\right)$ was divided in three transects (replication) where soil samples were collected at $0-5 \mathrm{~cm}$ depth around the rhizosphere (twenty plants per transect where the soil adhered to the roots were collected and mixed to form a composite sample per transect). All soil samples were immediately stored in sealed plastic bags and transported in an icebox to the laboratory. A portion of each soil sample was stored in bags and kept at $-80^{\circ} \mathrm{C}$ for DNA analysis and another portion was air-dried, sieved through a 2-mm screen, and homogenized for chemical and Physical analyses. The soil samples were conducted at the Laboratory of Soil of Agronomic Institute of Pernambuco stored at $-20{ }^{\circ} \mathrm{C}$ and estimated according to Embrapa (1997), are shown in Table I.

Total DNA was extracted from $0.5 \mathrm{~g}$ (total humid weight) of soil using the HiPurA Soil DNA Purification Kit TM (HIMEDIA), according to the manufacturer's instructions. The DNA Extraction was performed in triplicate for each soil sample. The quality and concentration of the extracted DNA was determined using spectrophotometry and measures in 260 and $280 \mathrm{~nm}$. The ration 260/280 was calculated according to requirements of Macrogen Inc. (South Korea). Roche GS- FLX amplicon sequencing of bacterial diversity were characterized by high-throughput sequencing (454 GS FLX amplicon sequencing) (Binladen et al. 2007) by using the primer 27F/519R that targeted the variable region V1-V3 of $16 \mathrm{~S}$ rRNA bacterial gene (Fagervold et al. 2014, Kumar et al. 2011).

DNA samples were shipped to Macrogen Inc, South Korea Macrogen. Available:_http:// dna.macrogen.com/eng. for high-throughput 
Table I. Chemical and Physical characteristics of the soil sampled by each mesoregion the state of Pernambuco.

\begin{tabular}{|c|c|c|c|c|c|c|c|}
\hline SOIL PROPERTIES & $\begin{array}{l}\text { AGRESTE } \\
\text { ZONE }\end{array}$ & $\begin{array}{l}\text { TRANSITION } \\
\text { ZONE }\end{array}$ & $\begin{array}{l}\text { SERTÃO } \\
\text { ZONE }\end{array}$ & $\begin{array}{c}\text { SOIL } \\
\text { PROPERTIES }\end{array}$ & $\begin{array}{l}\text { AGRESTE } \\
\text { ZONE }\end{array}$ & $\begin{array}{l}\text { TRANSITION } \\
\text { ZONE }\end{array}$ & $\begin{array}{c}\text { SERTÃO } \\
\text { ZONE }\end{array}$ \\
\hline & \multicolumn{3}{|c|}{ Chemical characteristics } & \multicolumn{4}{|c|}{ Physical characteristics } \\
\hline $\mathrm{pH}\left(\mathrm{H}_{2} \mathrm{O}\right)$ & 5.5 & 5.7 & 5.5 & $\begin{array}{c}\text { Course Sand } \\
(\%)\end{array}$ & 48 & 30 & 54 \\
\hline$P\left(\mathrm{mg} \mathrm{dm}^{-3}\right)$ & 228 & 178 & 42 & Thin Sand (\%) & 19 & 36 & 20 \\
\hline $\mathrm{Ca}^{3+}\left(\mathrm{cmol}_{\mathrm{c}} \mathrm{dm}^{-3} \%\right)$ & 6.90 & 5.60 & 3.35 & Silt (\%) & 22 & 26 & 18 \\
\hline $\mathrm{Mg}^{2+}\left(\mathrm{cmol}_{\mathrm{c}} \mathrm{dm}^{-3} \%\right)$ & 0.75 & 1.00 & 1.05 & Clay (\%) & $\begin{array}{l}11 \\
S L\end{array}$ & $\begin{array}{c}8 \\
S L\end{array}$ & $\begin{array}{c}8 \\
S L\end{array}$ \\
\hline $\mathrm{Na}^{2+}\left(\mathrm{cmol}_{\mathrm{c}} \mathrm{dm}^{-3} \%\right)$ & 0.07 & 0.08 & 0.06 & \multicolumn{4}{|c|}{ Available water Inches of water/foot of soil } \\
\hline $\mathrm{K}^{+}\left(\mathrm{cmolc} \mathrm{dm}^{-3} \%\right)$ & 0.25 & 0.19 & 0.25 & $\begin{array}{l}\text { Field Capacity } \\
\quad(\mathrm{in} / \mathrm{ft})\end{array}$ & 8.36 & 6.15 & 6.22 \\
\hline $\mathrm{AL}^{3+}\left(\mathrm{cmol}_{\mathrm{c}} \mathrm{dm}^{-3} \%\right)$ & 0.10 & 0.05 & 0.10 & $\begin{array}{l}\text { Oven Dry (in/ } \\
\mathrm{ft} \text { ) }\end{array}$ & 1.12 & 0.95 & 0.90 \\
\hline $\mathrm{H}^{+}\left(\mathrm{cmol}_{\mathrm{c}} \mathrm{dm}^{-3} \%\right)$ & 4.93 & 3.90 & 3.20 & $\mathrm{Ds}(\mathrm{Kg} \mathrm{dm}-3)$ & 1.34 & 1.54 & 1.45 \\
\hline SB $\left(\mathrm{cmol}_{\mathrm{c}} \mathrm{dm}^{-3} \%\right)$ & 8.0 & 6.9 & 4.7 & $\mathrm{Dp}(\mathrm{Kg} d \mathrm{~m}-3)$ & 2.56 & 2.56 & 2.56 \\
\hline $\mathrm{T}\left(\mathrm{cmol}_{\mathrm{c}} \mathrm{dm}^{-3} \%\right)$ & 13.0 & 10.8 & 8.0 & & & & \\
\hline
\end{tabular}

T=Total Cation Exchange Capacity, SB- Sum of Bases, Ds-Soil Density, Dp- Particule Density; SL - sandy loam.

sequencing. GS FLX data processing was performed using Roche GS FLX software ( $v$ 2.9) in two stages, image processing and signal processing. Image processing involves normalization of raw images and generation of raw signals. In the signal processing stage, correction, filtering, and raw signal trimming were done prior to base calling with corresponding quality score of reads. Sequence reads from each sample were segregated with in-house script (Macrogen) using the tag (Barcode) sequences, and by matching the initial and final bases of the reads to the known tag sequences used in the preparation of the libraries (Lee et al. 2010). The sequences were processed using the Quantitative Insights Into Microbial Ecology toolkit (QIIME) (Caporaso et al. 2009, 2010). Sequences with quality > Q20 and homopolymers $>6$ were aligned. Barcodes were removed and the sequences of the expected size $(400 \mathrm{pb})$ were retained for further processing.
Chimeras were identified using Chimeraslayer and removed. Organelles and archaeal contaminations were also excluded within QIIME (Version 1.9.0) The sequences were grouped into OTUs with $97 \%$ similarity using UCLUST (Edgar 2010). A representative sequence of each OTU was aligned again in GreenGenes core set using PyNAST (Caporaso et al. 2010), with sequences classified in the database GreenGenes via UCLUST (Edgar 2010). The profiles of alpha and beta diversity were obtained according to the Qiime's 454 tutorial (http://qiime.org/tutorials/ tutorial.html). The analyses PCOA (Principal Coordinate Analyses) was used with QIIME The transformations used taxonomic (Bray-Curtis Distances) measures of the bacterial community composition considered all dimensions relevant between bacterial composition and zones (Fierer et al. 2012). We have applied the rarefaction procedure indicated in the qiime tutorial was applied (http://qiime.org/scripts/ 
core_diversity_analyses.html?highlight=core). After rarefaction, the libraries covered from 75.7$88.4 \%$ of the original sample based on Good's coverage.

\section{RESULTS AND DISCUSSION}

A total of 137,291 reads were obtained from soil samples and were clustered in 9,838 OTUs in Agreste, 8,388 OTUs in the Transition zone, and 14,849 OTUs for Sertão (Figure 1a). Although sertão zone has shown highest number of OTUs, the Shannon's diversity index was lowest in this area as compared with Agreste and Transition (Figure 1b). The PCOA of OTUs stands for significant differences between areas according to their bacterial community (Figure 2). The soils have a texture class of sandy loam, however, have differences in their physical and chemical characteristics, where the soils of the transition zone behave in a very characteristic way of a changing zone. The transition zone has a field capacity very similar to the Sertão region and

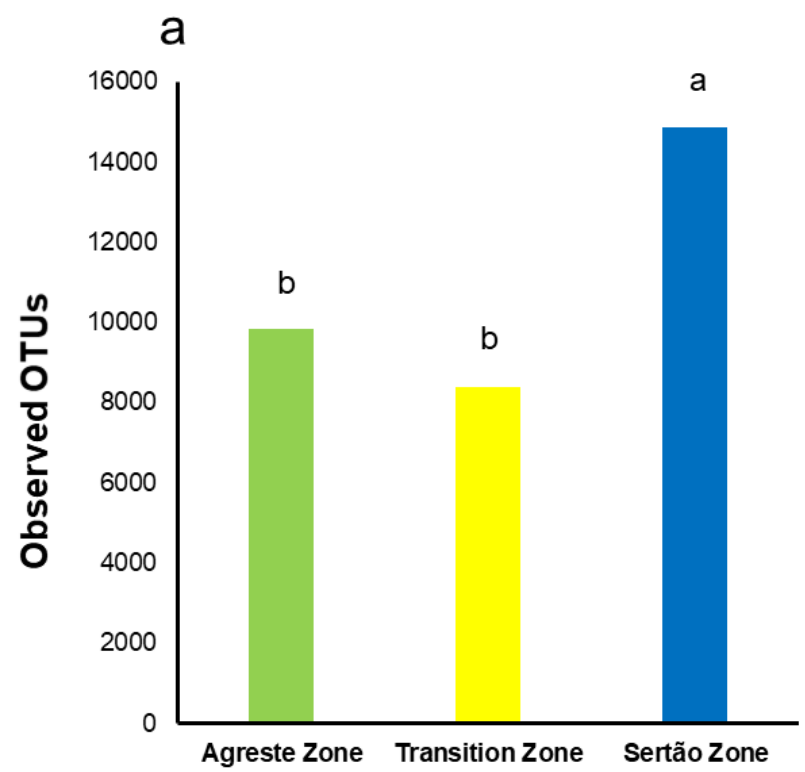

35\% smaller than the Agreste zone. The results showed that soil microbial communities in the transition zone have fewer OTUs than in the Agreste and Sertão zones. It is known that biotic and abiotic factors may be responsible for the composition and structures of communities, but a rhizospheric effect of soil microorganisms may increase or decrease the occurrence of OTUs. What we can infer is that the composition and structures of these communities in the transition zone may not be in equilibrium and therefore present a lower OTU value or present no similarities between collection points and periods. Andrew et al. (2012), studying abiotic factors in desert soil, observed that genetic diversity can be influenced by abiotic factors such as extreme temperature fluctuation, high UV radiation, low nutrient content and low soil moisture.

The results of OTUs richness found in this study contrast with those Shange et al. (2012) who observed increased richness in native and cultivated soil. However, the regions studied here were all cultivated with Prickly-Pear Cactus,

b

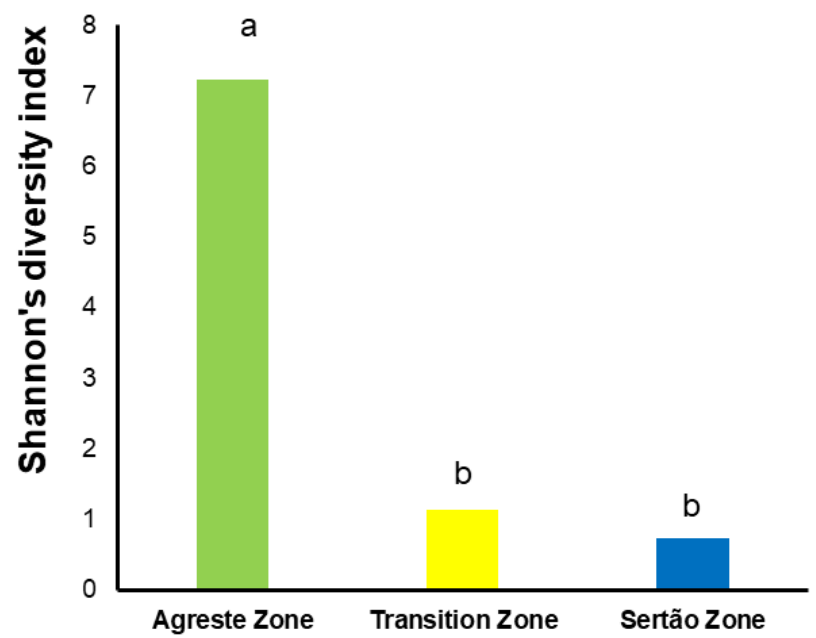

Figure 1. Observed OTUs (a) and Shannon's diversity index (b) in the mesoregions of the State of Pernambuco. Different lowercase letters refer to significant differences between treatments based on Tukey's HSD test (P < 0.05). 
which would not explain the observed variation. However, according to Barros (2007), for the richness estimated in tropical regions, curve stabilization is very difficult to attain because more rare species appear, and increased sampling efforts are needed. Thus, although the number of samples for the areas is the same for each region, local samples may be subject to different influences because species richness and diversity depend on factors beyond the natural community of nature and the sampling effort. On the other hand, Agreste presented highest diversity of bacterial communities than Transition and Sertão. The species richness and diversity of different species exhibit variations due to the biotic and abiotic factors that influence the distribution and species selection (Magurran 1988). In the Sertão Zone, we observed an increased value of richness and reduced diversity, where a reduced Shannon index value can be attributed to the reduced richness of the high dominance taxonomic groups.

Eight most abundant phyla (Proteobacteria, Actinobacteria, Acidobacteria, Chloroflexi, Firmicutes, Bacteroidetes, Planctomycetes, and the candidatus phyla TM7), with percentages of OTUs above $1 \%$, represented more than $90 \%$ of the total OTUs (Figure 3). Three most abundant phyla were Proteobacteria, Actinobacteria, and Acidobacteria found in all areas. Proteobacteria and Acidobacteria were abundant in Agreste and Sertão, respectively, while Actinobacteria were abundant in Transition and Sertão.

Proteobacteriaarethemostabundantphylum in the soil bacterial community and exhibited a greater dominance of $70 \%$ in dry environmental samples (Xu et al. 2014, Taketani et al. 2015, Kavamura et al. 2013, Lançoni et al. 2013). The results showed that Agreste presented highest abundance of Proteobacteria, while Sertão presented highest abundance of Acidobacteria. These findings suggest that differences in soil conditions could regulate the abundance of these groups. Indeed, Sertão presents highest temperature and lowest soil moisture and fertility, and these conditions contributes for increasing the abundance of Acidobacteria which are adapted to poor soils and extreme environment (Rousk et al. 2010). On the other hand, Agreste zone presents better soil fertility

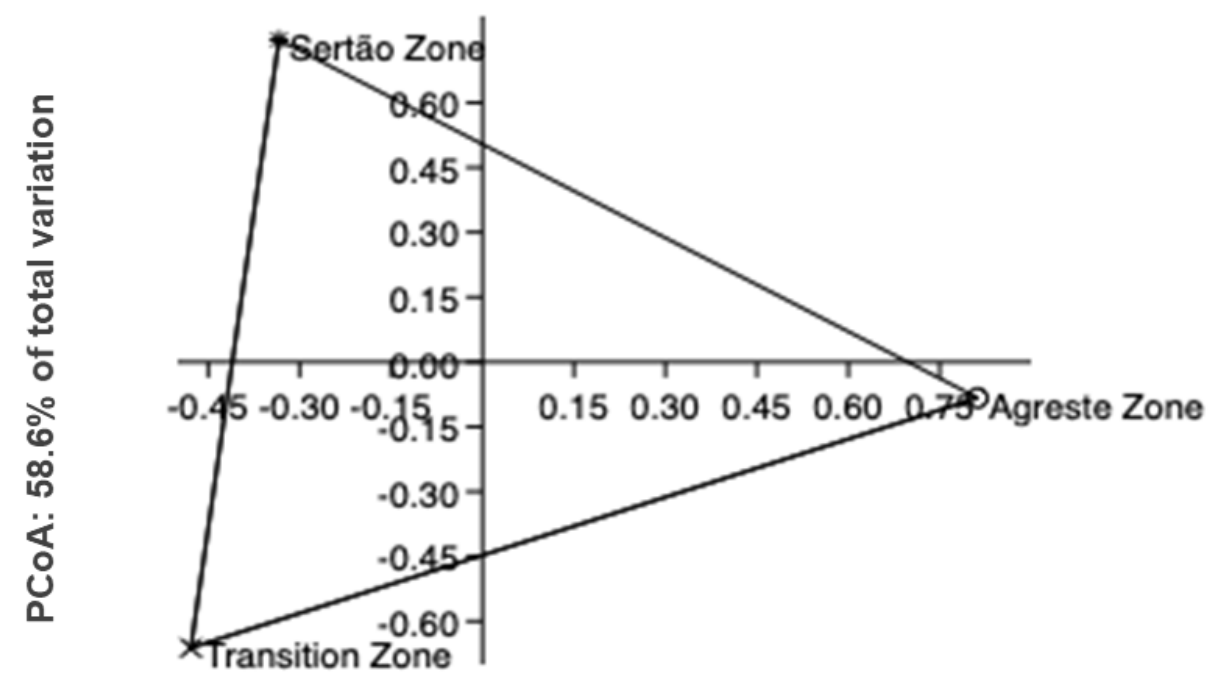

Figure 2. PCoA plots in the mesoregions of the State of Pernambuco.

PCoA: $\mathbf{4 1 . 3} \%$ of total variation 
than Sertão and it contributed for increasing the abundance of Proteobacteria. According to studies from Fierer et al. (2007) and Singh et al. (2010) Proteobacteria have a copiotroph (require high nutrients concentrations) lifestyle, whereas Acidobacteria are oligotrophic (require very low nutrients concentrations). This finding is interesting because in the case of the PricklyPear cactus crops, which underwent intensive farming, copiotroph bacteria should already be present. Actinobacteria were detected with higher abundance in Transition and Sertão zones. These bacteria play important role in the organic matter decomposition in soil (Kopecky et al. 2011) and, therefore, are important for these areas since they presented low soil fertility.

Bacteria from the group of $\alpha$ and $y$-Proteobacteria were predominant in Agreste (37\% and $13 \%$, respectively) and the percentages were reduced in the Transition and Sertão zones. In Transition and Sertão zones, the largest predominance of Actinobacteria included Thermoleophilia (13 and 18\%, respectively) and Actinobacteria (24 and 15\%, respectively) at the class level. Considering percentages of OTUs above $5 \%$, we found the family Gaiellales with presence in the most arid region (Sertão). In contrast, the families Rhizobiales and Rhodospirillales exhibited an increased incidence in the Transition and Agreste zones. As the temperature decreases and the rainfall increases, the predominance of the orders Rhizobiales and Rhodospirillales is observed. Families with abundance above 5\% included Caulobacteraceae, Bradyrhizobiaceae and Hyphomicrobiaceae, Acetobacteraceae and Rhodospirillaceae (Figure 4). The remaining families have a prevalence lower than $5 \%$.

The results of this study clearly demonstrate that the different zones of Agreste, Transitions, and Sertão have distinct bacterial communities and it is influenced by environmental and soil conditions. Since that each zone presents the same plant species, the difference in bacterial community is associated with the environment which also influence the plant responses. Our study also demonstrate that semi-arid soils are environments where natural selection has

SERTÃO ZONE

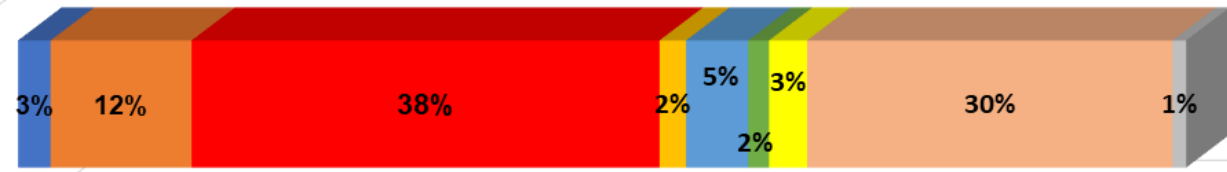

TRANSITION ZONE

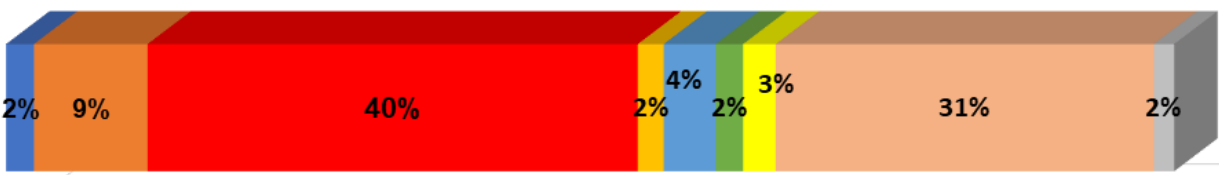

AGRESTE ZONE
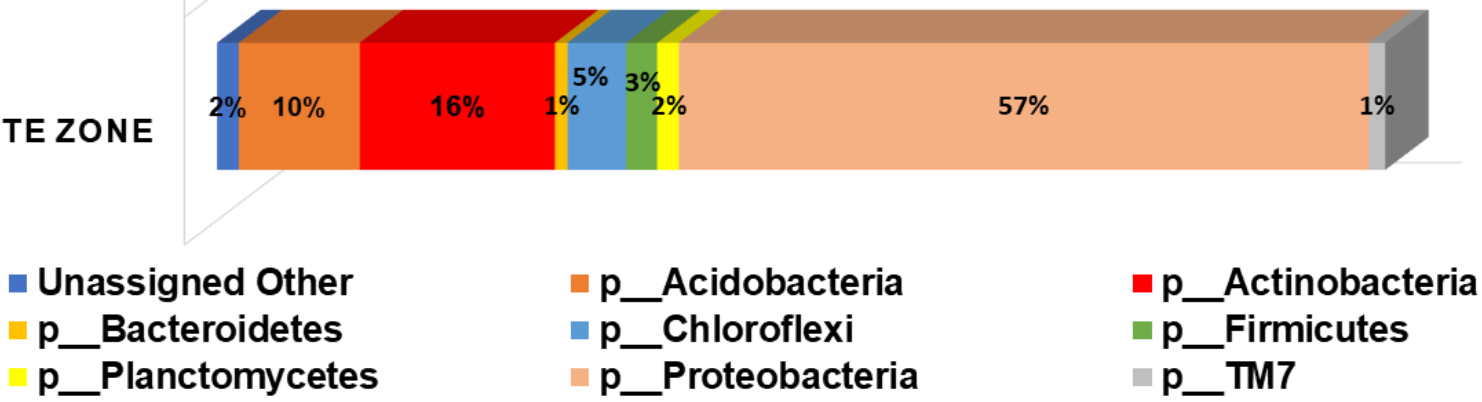

Figure 3. Relative abundance of the major taxonomic groups observed in the mesoregions of the State of Pernambuco. 


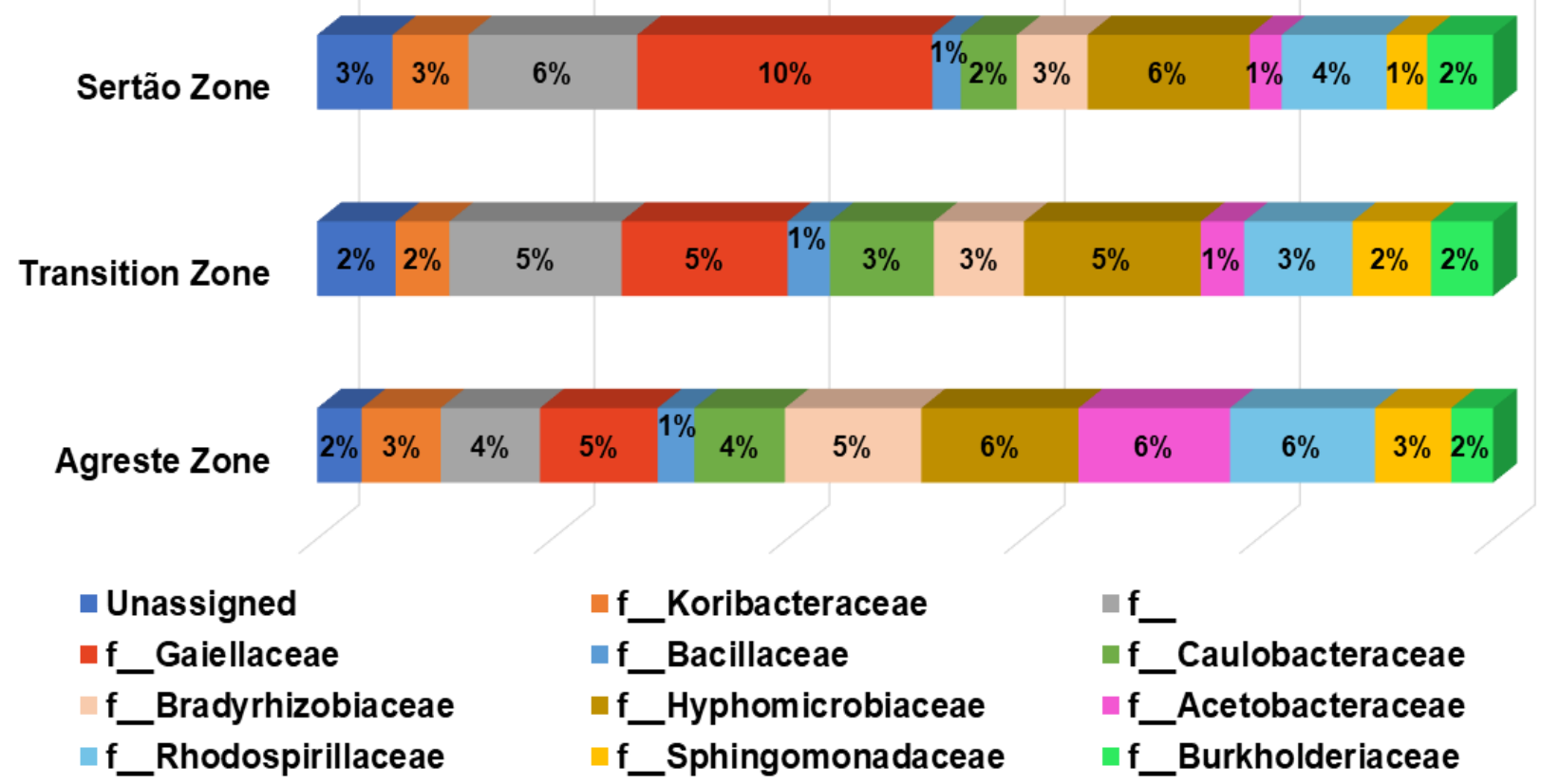

Figure 4. Taxonomic distribution of the microbial community of the soil at the level of family observed in mesoregions the state of Pernambuco.

resulted in the selection of organisms that resist extreme variation of climatic factors, such as the incidence of rain and high temperatures (Collins et al. 2008). Prickly-Pear Cactus are in the Cactaceae family, which is highly adapted to the semi-arid region. In the rhizosphere of these plants, it is possible that microbial communities interact with the Prickly-Pear Cactus roots.

Finally, in the Pernambuco semiarid region, the Caatinga is poorly studied, specifically on the structure of microbial communities and their roles in the environment. Thus, further studies are important understanding the role of these microorganisms and their adaptation to local plant species, such as the Prickly-Pear Cactus, which is important for this region.

\section{CONCLUSIONS}

This study showed the establishment of distinct bacterial communities in soils of different regions of Caatinga biome, i.e. Agreste, Transition, and Sertão. Therefore, the structure and diversity of bacterial community were different in these areas and were influenced by environmental and soil conditions. In addition, the PricklyPear Cactus, as a highly adapted to semi-arid plant, can significantly modify the diversity of these micro-organisms. Future studies should be conducted to elucidate and validate the discrepancies identified in some taxa.

\section{Acknowledgments}

Thanks to Coordenação de Aperfeiçoamento de Pessoal de Nivel Superior - CAPES/ Programa Nacional de PósDoutorado- PNPD/ Financiadora de Estudos e ProjetosFINEP (N02714/09-4) for financial support. Dra. Paula Regina Kuser Falcão EMBRAPA, Agricultural Informatics to have received the first author in his group to carry out the bioinformatic analyzes and Dr. José Geraldo Eugênio de França - IPA, for the effort to send the first author to EMBRAPA Agricultural informatics and to obtain financial support to do the analyzes in Campinas and Jaguariúna - EMBRAPA Environment.

\section{REFERENCES}

ANDREW DR, FITAK RR, MUNGUIA-VEGA A, RACOLTA A, MARTINSON VG \& DONTSOVA K. 2012. Abiotic factors shape 
microbial diversity in Sonoran Desert soils. Appl Environ Microbiol 78: 7527-7537. https://aem.asm.org/content/ aem/78/21/7527.full.pdf.

BAIS HP, WEIR TL, PERRY LG, GILROY S \& VIVANCO JM. 2006. The role of root exudates in rhizosphere interactions with plants and other organisms. Annu Rev Plant Biol 57: 233-266. https://www.annualreviews.org/doi/10.1146/ annurev.arplant.57.032905.105159.

BARDGETT R. 2005. The biology of soil: a community and ecosystem approach. Cap. 2: The diversity of life in soil. Oxford University Press: Great Britain, p. 24-55. ISBN: 0-19-852503-6.

BARROS RS. 2007. Medidas de diversidade biológica. Programa de Pós-Graduação em Ecologia Aplicada ao Manejo e Conservação de Recursos Naturais da Universidade Federal de Juiz de Fora, Minas Gerais. http://files.profdonizetti.webnode. com/20000050218c9819c35/Artigo_MedidasDiversidade. pdf.

BINLADEN J, GILBERT MTP, BOLLBACK, JP, PANITZ F, BENDIXEN C, NIELSEN R \& WILLERSLEV E. 2007. The use of coded PCR primers enables high-throughput sequencing of multiple homolog amplification products by 454 parallel sequencing. PLoS ONE 2(2): e197. https://doi.org/10.1371/ journal.pone.0000197.

CAPORASO JG, BITTINGER K, BUSHMAN FD, DESANTIS TZ, ANDERSEN GL \& KNIGHT R. 2009. PyNAST: a flexible tool for aligning sequences to a template alignment. Bioinformatics 26(2): 266-267. https://doi.org/10.1093/bioinformatics/ btp636.

CAPORASO JG, KUCZYNSKI J, STOMBAUGH J, BITTINGER K, BUSHMAN FD, COSTELLO EK \& HUTTLEY GA. 2010. QIIME allowS analysis of high-throughput community sequencing data. Nat Methods 7(5): 335. https://www.nature.com/ articles/nmeth.f.303.

COLLINS SL, SINSABAUGH RL, CRENSHAW C, GREEN L, PORRASALFARO A, STURSOVAM \& ZEGLIN LH. 2008. Pulse dynamics and microbial processes in aridland ecosystems. J Ecol 96(3): 413-420. https://doi.org/10.1111/j.1365-2745.2008.01362.x.

DE BM TROVÃO DM, FERNANDES PD, DE ANDRADE LA \& NETO JD. 2007. Variações sazonais de aspectos fisiológicos de espécies da Caatinga. R Bras Eng Agríc Ambiental 11(3): 307-311. http://www.scielo.br/pdf/rbeaa/v11n3/a10v11n3.

EDGAR RC. 2010. Search and clustering orders of magnitude faster than BLAST. Bioinformatics 26(19): 2460-2461. https://doi.org/10.1093/bioinformatics/btq461.

EMBRAPA. 1997. Manual de métodos de análises de solo. In: Rio de Janeiro, Ministério da Agricultura e do Abastecimento 2. 212 p. https://www.agencia.cnptia. embrapa.br/Repositorio/Manual+de+Metodos_000fzvh otqk02wx5ok0q43a0ram31wtr.pdf.

FAGERVOLD SK, ROMANO C, KALENITCHENKO D, BOROWSKI C, NUNES-JORGE A, MARTIN D \& GALAND PE. 2014. Microbial communities in sunken wood are structured by wood-boring bivalves and location in a submarine canyon. PLoS ONE 9(5): e96248. https://doi.org/10.1371/ journal.pone.0096248.

FIERER N, BRADFORD MA \& JACKSON RB. 2007. Toward an ecological classification of soil bacteria. Ecology 88(6): 1354-1364. https://doi.org/10.1890/05-1839.

FIERER N, LAUBER CL, RAMIREZ KS, ZANEVELD J, BRADFORD MA \& KNIGHT R. 2012. Comparative metagenomic, phylogenetic and physiological analyses of soil microbial communities across nitrogen gradients. ISME J 6(5): 1007. https://www. nature.com/articles/ismej2011159.

HORNER-DEVINE MC, LAGE M, HUGHES JB \& BOHANNAN BJ. 2004. A taxa-area relationship for bacteria. Nature 432(7018): 750. https://www.nature.com/articles/nature03073.

KAVAMURA VN, TAKETANI RG, LANÇONI MD, ANDREOTE FD, MENDES R \& DE MELO IS. 2013. Water regime influences bulk soil and rhizosphere of Cereus jamacaru bacterial communities in the Brazilian Caatinga biome. PLoS ONE 8(9): e73606. https://doi.org/10.1371/journal.pone.0073606.

KLINDWORTH A, PRUESSE E, SCHWEER T, PEPLIES J, QUAST C, HORN M \& GLÖCKNER FO. 2013. Evaluation of general 16S ribosomal RNA gene PCR primers for classical and nextgeneration sequencing-based diversity studies. Nucleic Acids Res 41(1): e1-e1. https://doi.org/10.1093/nar/gks808.

KOPECKY J, KYSELKOVA M, OMELKA M, CERMAK L, NOVOTNA J, GRUNDMANN GL \& SAGOVA-MARECKOVA M. 2011. Actinobacterial community dominated by a distinct clade in acidic soil of a waterlogged deciduous forest. FEMS Microbiology Ecology 78(2): 386-394. https:// doi.org/10.1111/j.1574-6941.2011.01173.x.

KUMAR PS, BROOKER MR, DOWD SE \& CAMERLENGOT. 2011. Target region selection is a critical determinant of community fingerprints generated by $16 \mathrm{~S}$ pyrosequencing. PLoS ONE 6(6): e20956. https://doi.org/10.1371/journal. pone.0020956.

LANÇONI MD, TAKETANI RG, KAVAMURA VN \& DE MELO IS. 2013. Microbial community biogeographic patterns in the rhizosphere of two Brazilian semi-arid leguminous trees. World J of Microbiol and Biotechnol 29(7): 1233-1241. https://link.springer.com/article/10.1007/ s11274-013-1286-4.

LEE TK, VAN DOAN T, YOO K, CHOI S, KIM C \& PARK J. 2010. Discovery of commonly existing anode biofilm microbes in two different wastewater treatment MFCs using FLX Titanium pyrosequencing. Appl Microbiol Biotechnol 87(6): 2335-2343. https://link.springer.com/ article/10.1007/s00253-010-2680-6.

MAGALHÃES ACN \& FERRI MG. 1979. Fotossíntese. Fisiologia Vegetal 1(2): 117-168.

MAGURRAN AE. 1988. Why diversity? In: Ecological diversity and its measurement. Springer: Dordrecht, p. 1-5. 
PHILIPPOT L, RAAIJMAKERS JM, LEMANCEAU P \& VAN DER PUTTEN WH. 2013. Going back to the roots: the microbial ecology of the rhizosphere. Nat Rev Microbiol 11(11): 789. https:// www.nature.com/articles/nrmicro3109.

ROUSK J, BÅÅTH E, BROOKES PC, LAUBER CL, LOZUPONE C, CAPORASO JG, KNIGHT R \& FIERER N. 2010. Soil bacterial and fungal communities across a pH gradient in an arable soil. ISME J 4(10): 1340. https://www.nature.com/ articles/ismej201058.

SHANGE RS, ANKUMAH RO, IBEKWE AM, ZABAWA R \& DOWD SE. 2012. Distinct soil bacterial communities revealed under a diversely managed agroecosystem. PLoS ONE 7(7): e40338. https://doi.org/10.1371/journal.pone.0040338.

SILVA JD, TABARELLI M, FONSECA MD \& LINS LV. 2004. Biodiversidade da Caatinga: áreas e ações prioritárias para a conservação. Ministério do Meio Ambiente, Brasília. Brasília: Ministério do Meio Ambiente, 2004. https://www.terrabrasilis.org.br/ecotecadigital/pdf/ biodiversidade-da-caatinga-areas-e-acoes-prioritariaspara-a-conservacao-.pdf.

SINGH BK, BARDGETT RD, SMITH P \& REAY DS. 2010. Microorganisms and climate change: terrestrial feedbacks and mitigation options. Nat Rev Microbiol 8(11): 779. https://www.nature.com/articles/nrmicro2439.

TAKETANI RG, KAVAMURA VN, MENDES R \& MELO IS. 2015. Functional congruence of rhizosphere microbial communities associated to leguminous tree from Brazilian semiarid region. Environ Microbiol Rep 7(1): 95101. https://doi.org/10.1111/1758-2229.12187.

XU Z, HANSEN MA, HANSEN LH, JACQUIODS \& SØRENSEN SJ. 2014. Bioinformatic approaches reveal metagenomic characterization of soil microbial community. PLoS ONE 9(4): e93445. https://doi.org/10.1371/journal. pone.0093445.

\section{How to cite:}

DE LYRA MCCP, TAKETANI RG, DE FREITAS ADS, E SILVA CERS, MERGULHÃO ACES, DA SILVA MLRB, ANTUNES JELS, DE ARAÚJO ASF \& GIACHETTO PF. 2021. Structure and diversity of bacterial community in semiarid soils cultivated with prickly-pear cactus (Opuntia ficus-indica (L.) Mill.) An Acad Bras Cienc 93: e20190183. DOI 10.1590/0001-3765202120190183.

Manuscript received on February 15, 2019;

accepted for publication on July 05, 2019

MARIA DO CARMO C.P. DE LYRA ${ }^{1}$

https://orcid.org/0000-0003-1010-1692

RODRIGO G. TAKETANI ${ }^{2}$

https://orcid.org/0000-0002-5999-8704

ANA DOLORES S. DE FREITAS ${ }^{3}$

https://orcid.org/0000-0001-5808-097X
CAROLINA E.R.S. E SILVA

https://orcid.org/0000-0001-8771-8055

\section{ADÁLIA C.E.S. MERGULHÃO'}

https://orcid.org/0000-0003-1148-9967

MARIA LUIZA R.B. DA SILVA ${ }^{1}$

https://orcid.org/0000-0002-8406-9472

JADSON E.L.S. ANTUNES

https://orcid.org/0000-0001-7122-2506

ADEMIR S.F. DE ARAÚJO 4

https://orcid.org/0000-0002-3212-3852

POLIANA F. GIACHETTO 5

https://orcid.org/0000-0002-9991-6566

${ }^{1}$ Instituto Agronômico de Pernambuco/IPA, Laboratório de Genômica, Avenida General San Martin, 1371, Bongi, 50761-000 Recife, PE, Brazil

2EMBRAPA Meio Ambiente, Rodovia SP-340, Km 127,5, Tanquinho Velho, Caixa Postal 69, 13820-000 Jaguariúna, SP, Brazil

${ }^{3}$ Universidade Federal Rural de Pernambuco/UFRPE, Laboratório de Microbiologia, Rua Dom Manoel de Medeiros, s/n, Dois irmãos, 52171-900 Recife, PE, Brazil

${ }^{4}$ Universidade Federal do Piauí, Centro de Ciências Agrárias, Rua Dirce de Oliveira, 3579, Campus da Soccopo, 64049-550 Teresina, PI, Brazil

${ }^{5}$ EMBRAPA Informática Agropecuária, Av. Dr. André Tosello, 209, Cidade Universitária, 13083-886 Campinas, SP, Brazil

Corresponding to: Maria do Carmo C.P. de Lyra

E-mail:mccatanho@gmail.com

\section{Author contributions}

The authors Maria do Carmo C. P. de Lyra and Poliana Gianchetto were the mentors of the work and the first author responsible for writing it, and both participated in all phases of the project. Ana Dolores S. Freitas and Carolina Santos collected all samples in the field. Adália Mergulhão, Maria L. Bastos and Jadson Antunes were responsible for the analyzes in the Laboratory and the researcher Ademir Araújo helped with the manuscript by making many contributions to it and the Researcher Rodrigo Taketani was responsible for all the bioinformatics analysis.

\section{(cc) BY}

